\title{
Mineral Composition of Some Latgale Lake Sediments
}

\author{
Rasma Tretjakova \\ Faculty of Engineering \\ Rezekne Academy of Technologies \\ Rēzekne, Latvia \\ rasma.tretjakova@rta.lv
}

\author{
Andris Karpovičs \\ Faculty of Engineering \\ Rezekne Academy of Technologies \\ Rēzekne, Latvia \\ andris.karpovics@rta.lv
}

\begin{abstract}
Our research is focused on sedimentological conditions and postdepositional changes of recent fine grained lake sediments. We used bulk sediment mineralogical composition and grain size distribution as indicators to identify sediment source areas and possible changes during Holocene. We analysed fine grained (clayey) sediments from three Latgale lakes - Zeili, Paugulii and Plusons, situated in Latgale upland. Lake sediments cover Late Pleistocene glacial deposits - loam and sandy loam. Bulk mineral composition of 6 sediment samples was determined by X-ray diffraction (XRD). Sediments contained typical minerals found in surrounding glacial sediments: rock-forming minerals as quartz, plagioclase, albite, enstatite, dolomite, calcite, and clay minerals - illite, kaolinite. To identify postdepositional changes in lake sediments of Holocene age clay minerals in clay fraction $(<2 \mathrm{mkm})$ should be analysed. Particularly illite, smectite mixed layered minerals - illite/smectite (I/Sm) and chlorite. Additionally, grain size distribution of studied lake sediments was analysed. Accordingly, our studied sediments are clays, silty clays and clayey silts with bimodal particle distribution, except two samples from Zeili and Plusons with unimodal distribution.
\end{abstract}

Keywords - lacustrine sediments, minerals, clay, XRD, Latgale.

\section{INTRODUCTION}

Recent (Holocene) lake deposits in Latvia are widely studied, but most of research covers organic deposits - sapropel and peat [1], [2]. On the other hand, much research has been done on lacustrine mineral sediments, but mostly glacial lake sediments [3], [4]. Sediment grain size distribution [5], mineral composition and clay minerals alone [6], [7] or combined with other parameters are widely used to reconstruct past climates from marine and lacustrine sedimentary record [1]-[4], [8]-[10]. Better than bulk mineral composition, clay minerals may serve as effective tools to establish the origin of fine-grained terrigenous sediment of seas [11, 12] and lakes [13]. Review of scientific literature revealed that clay minerals, their ratios and variety of mineralogical indices, as crystallinity degree of illite (Kübler index), crystallinity degree of chlorite (Àrkai index), P index (describes mutual relations between neoformed and detrital mineral phases) as well as others may be applied for sedimentological and paleoclimatic reconstructions $[6,7],[15,16]$.

The goal of this study is to assess clay mineral composition and grain size distribution of fine grained recent lacustrine sediments as indicators for sedimentological conditions, and postdepositional changes of recent fine grained lake sediments. In this article, we are presenting pilot stage of the study where mineralogical composition, with particular interest in clay minerals, of lake sediments were analysed. Hence, amount of samples was insufficient for further analysis, grain size analysis served mostly for classification purpose.

\section{MATERIALAS AND METHODS}

We analysed lacustrine sediments from 3 Latgale (historical and cultural region in eastern part of Latvia) lakes - Zeili, Paugulii and Plusons (see Fig. 1). Studied lakes are situated in marginal zone of Latgale upland which is an insular accumulative-glaciostructural upland. Zeili and Pauguli lakes are situated in morainic hummocky area, in the north of Latgale upland. Plusons on the other hand is situated in area dominated by kames and eskers formed of glaciofluvial and glaciolimnic sediments. According to database of Latvian lakes [17] studied lakes are shallow, with mean water depths from 1.1 to 2.5 metres. Area of water surface of Zeili and Pauguli is 44.8 ha and 22.0 ha accordingly but Plusons -480 ha [17]. Lake beds are formed in Weichselian age glacigenic and glaciofluvial sediments and filled with mainly fine grained sediments. Clays and silty clays in Zeili and Pauguli and fine sand, silt and clayey silt in Plusons. In all studied lakes inorganic sediments are covered by organic mud and sapropel up to 4 metres thick (in Zeili).

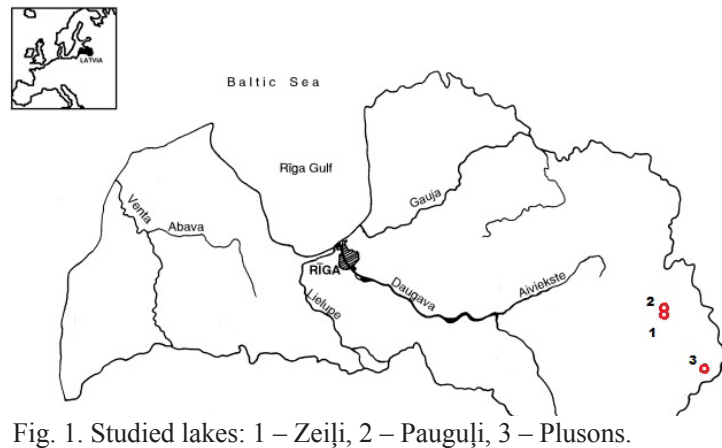

Print ISSN 1691-5402

Online ISSN 2256-070X http://dx.doi.org/10.17770/etr2019vol1.4146 (C) 2019 Rasma Tretjakova, Andris Karpovičs.

Published by Rezekne Academy of Technologies. This is an open access article under the Creative Commons Attribution 4.0 International License. 
In total 6 samples of fine grained lacustrine sediments were analysed. Zeili represents four samples from two boreholes at various depths (6 to $8 \mathrm{~m}$ ) and two from lakes Pauguli (3.5 $\mathrm{m})$ and Plusons $(8.0 \mathrm{~m})$ accordingly. Sampling was carried out in winter with help of geological hand auger (the "Eijkelkamp" type). Clay samples were placed into sterile plastic zip lock bags and stored refrigerated. Grain-size and mineralogical composition within the clay samples is analysed in Riga Technical University Institute of Silicate Materials, Faculty of Materials Science and Applied Chemistry.

X-ray diffraction (XRD) analyses [18] of samples were run by Rigaku - Ultima + diffractometer with $\mathrm{Cu}$ tube at $40 \mathrm{kV}$ and $5 \mathrm{~mA}$ in spinning mode. The analyses range was from $5^{\circ}$ to $60^{\circ} 2 \theta$ and scanning speed $1^{\circ} / \mathrm{min}$. Data processing was carried out by MDI Jade 9 software and identification of minerals using ICDD data base (PDF-4 Organics2017) [19].

Grain size analyses were run by Broohkaven Instruments particle size analyser based on the principles of Dynamic Light Scattering (DLS). Instrument allows to detect particles in range from $1.5 \mathrm{~nm}$ to $3 \mathrm{mkm}$.

\section{RESULTS AND DISCUSION}

Mineralogical (XRD) analyses of some Latgale lakes fine grained sediments shows that their mineralogical composition is similar. Mineral composition of quaternary clay (fraction $<2 \mu \mathrm{m}$ ) in Latvia is quite uniform, most abundant clay mineral is illite $(75-80 \%)$ followed by kaolinite (until 20\%) and chlorite (5-10\%) [20].

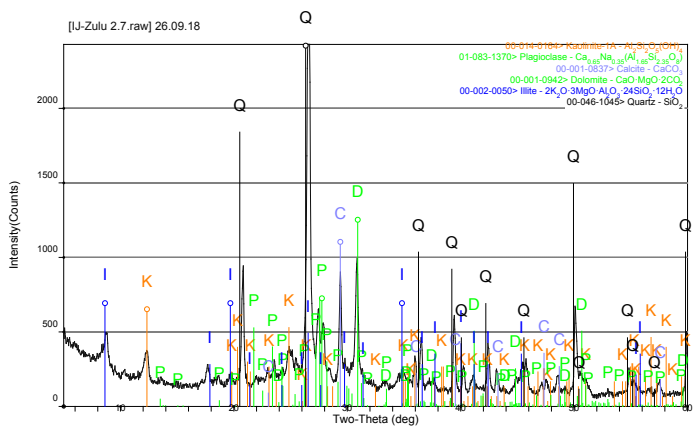

Fig. 2. X-ray difraction pattern of clayey sample from lake Zeil̦i, sampling depth $7 \mathrm{~m}$. Minerals: $\mathrm{Q}$ - quartz, $\mathrm{P}$ - plagioclase, $\mathrm{C}-$ calcite, $\mathrm{D}$ - dolomite, I - illite, $\mathrm{K}$ - kaolinite.

Studied lake sediment mineral assemblages consist of rock forming minerals as quartz, plagioclase, albite, enstatite, dolomite, calcite, and clay minerals - illite and kaolinite (Fig. 1 - 3). In lake Zeili we analysed mineralogical composition from two cores - 6 to $8 \mathrm{~m}$ and 1 sample from $8 \mathrm{~m}$. Depth wise bulk mineral composition does not change - quartz, feldspars, illite and kaolinite. But if analysed low angle $\left(2 \Theta<20^{\circ}\right)$ area of diffractograms, particulary illite peak at $2 \Theta=\sim 7^{\circ}$ (Fig. 1 and Fig. 2) there are some features in XRD spectra indicating changes in illite. Our hypothesis is that there is a mixed layer of illite/ smectite as well as illite with various degree crystallinity. To confirm our hypothesis more detailed sampling and analysis of mentioned features as well as quantitative analysis of clay minerals is needed.
Mineralogical composition of fine grained sediments of lakes Pauguli and Zeili is similar (Fig. 1 and Fig. 2). Similarly to case of Zeiļi, sediments of Pauguli hypothetically may contain illite with various degree of crystallinity and admixture of interlayer illite/smectite (I/ $\mathrm{Sm})$.

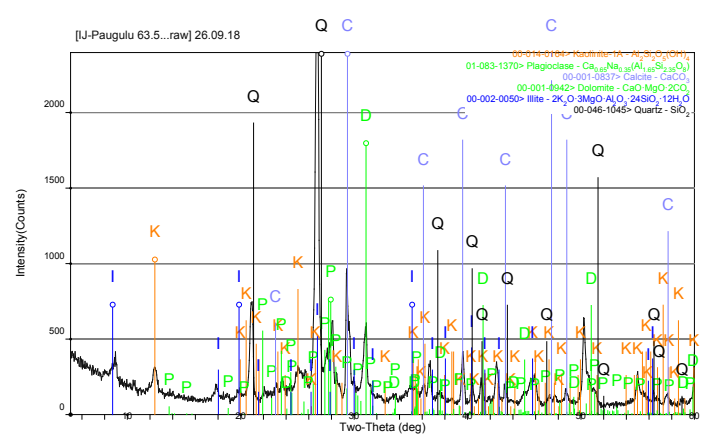

Fig. 3. X-ray difraction pattern of clayey sample from lake Pauguḷi, sampling depth $3.5 \mathrm{~m}$. Minerals: $\mathrm{Q}$ - quartz, $\mathrm{P}$ - plagioclase, $\mathrm{C}-$ calcite, D - dolomite, I - illite, $\mathrm{K}$ - kaolinite.

In contrast, fine grained sample from Plusons contained no clay minerals, but it contains calcite, dolomite, quartz, albite and pyroxene mineral - enstatite (Fig. 3). Pyroxenes are one of first silicate minerals to be dissolved and that why are rear in sediments [21]. Lack of clay minerals might reflect grain size distribution of sample. According to grain size analysis, Plusons is the coarsest of all samples and still consists of very fine silt particles. Hence there is only one sample from Plusons it is not possible to draw any more conclusions.

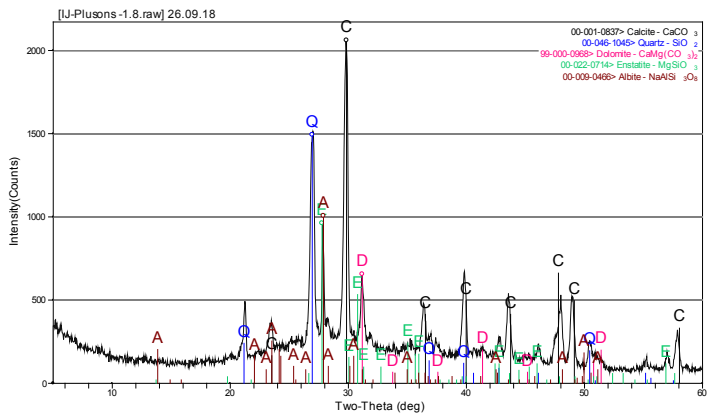

Fig. 4. X-ray difraction pattern of clayey sample from lake Plusons, sampling depth $8 \mathrm{~m}$. Minerals: Q - quartz, A - albite, E - enstatite, C calcite, D - dolomite.

Grain size distribution of studied lake sediments allow to classify them as clays, silty clays and clayey silts. Most of analysed sediments are characterized by bimodal particle distribution except two samples from Zeili and Plusons accordingly by unimodal distribution. Hence we have only 6 samples, no further analysis is reasonable. Scientific literature review indicates that there is still uncertainty in explaining genesis of lake sediment grain size components due to complexity of their bi- and polymodal distributions $[22,23]$.

\section{CONCLUSIONS}

Our study let us to draw some conclusions and envision further development of the study. The bulk 
mineral composition of studied lake sediments reflects mineral composition of typical Quaternary glacial sediments of Latvia. Mineral assemblage of studied sediments is overall similar, except of Plusons because of lack of clay minerals. We detected some features in XRD spectra indicating changes in illite. We advanced a hypothesis that there is a mixed layer of illite/smectite as well as illite with various degree crystallinity. To confirm our hypothesis more detailed sampling and analysis of mentioned features as well as quantitative analysis of clay minerals is needed. According to grain size distribution, studied lake sediments are clays, silty clays and clayey silts. Analysed sediments are characterized by bimodal and unimodal particle distribution.

\section{REFERENCES}

[1] K. Stankevica, L. Kalnina, M. Klavins, A. Cerina, L. Ustupe, E. Kaup, "Reconstruction of the Holocene palaeoenvironmental conditionsaccordingly to the multiproxy sedimentary records from Lake Pilvelis, Latvia," Quaternary International, vol. 386, pp. 102 115, 2 November 2015. i

[2] I. Ozola, A. Cerina, L. Kalnina, "Reconstruction of palaeovegetation and sedimentation conditions in the area of ancient Lake Burtnieks, northern Latvia," Estonian Journal of Earth Sciences, 59(2), pp. 164-179, June 2010.

[3] M. Nartišs, E. Kalińska-Nartiša, "An aeolian or a glaciolacustrine record? A case study from Miel̦upīte, Middle Gauja Lowland, northeast Latvia," Geologos, vol. 23, no. 1, pp. 15-28, 2017. https://doi.org/10.1515/logos-2017-0002.

[4] M. Nartišs, "Ice Meltwater Lakes of Northern Vidzeme and Middle Gauja Lowlands during the Late Weichselian Deglaciation," Summary of Doctoral thesis, University of Latvia, Riga, 2014. https://doi.org/10.13140/RG.2.2.28342.80964

[5] E. Kalińska-Nartiša, N. Stivrins, I. Grudzinska, "Quartz grains reveal sedimentary palaeoenvironment and past storm events: A case study from eastern Baltic," Estuarine, Coastal and Shelf Science, vol. 200, pp. 359-370, 5 January 2018. https://doi.org/10.1016/j. ecss.2017.11.027

[6] N. Fagel, X. Boës "Clay-mineral record in Lake Baikal sediments: The Holocene and Late Glacial transition," Palaeogeography, Palaeoclimatology, Palaeoecology, vol. 259, pp. 230-243, 2008. https://doi.org/10.1016/j.palaeo.2007.10.009

[7] F. X.Gingele, T. Leipe, "Clay mineral assemblages in the western Baltic Sea: recent distribution and relation to sedimentary units", Marine Geology vol. 140, no. 1-2, pp. 97-115, July 1997. https:// doi.org/10.1016/S0025-3227(97)00023-6

[8] P. Sümegi, S. Gulyás, G. Persaits, "Holocene paleoclimatic and paleohydrological changes in the Sárrét basin, NW Hungary," Documenta Praehistorica, vol. 35, pp. 25-31, 2008.

[9] M. Heikkila, H. Seppa, "Holocene climate dynamics in Latvia, eastern Baltic region: a pollen-based summer temperature reconstruction and regional comparison" Boreas, 39 (2010), pp.
705-719, 2010. https://doi.org/10.1111/j.1502-3885.2010.00164.x

[10]E.C. Grimm, J.J. Donovan, K.J. Brown, “A high-resolution record of climate variability and landscape response from Kettle Lake, northern Great Plains, North America," Quaternary Science Reviews, vol. 30, pp. 2626-2650, 2011. https://doi.org/10.1016/j. quascirev.2011.05.015

[11] R. Adriaens, E. Zeelmaekers, M. Fettweis, E. Vanlierde, J. Vanlede, P. Stassen, J. Elsen, J. Środoń, N. Vandenberghe, "Quantitative clay mineralogy as provenance indicator for recent muds in the southern North Sea", Marine Geology, vol. 398, pp. 48-58, 2018, https://doi.org/10.1016/j.margeo.2017.12.011.

[12]B. Segvic, A. Benvenuti, A. Moscariello, "Illite-smectite-rich clay parageneses from Quaternary tunnel valley sediments of the Dutch southern North Sea-mineral origin and paleoenvironment implications", Clays and Clay Minerals, vol. 64, pp. 608-627, 2016.

[13]S. Opitz, A. Ramisch, J. IJmker, F. Lehmkuhl, S. Mischke, G. Stauch, B. Wünnemann, Y. Zhang, B. Diekmann, "Spatio-temporal pattern of detrital clay-mineral supply to a lake system on the north-eastern Tibetan Plateau, and its relationship to late Quaternary paleoenvironmental changes", Catena, vol. 137, pp. 203-218, 2016, https://doi.org/10.1016/j.catena.2015.09.003.

[14]M. Frouin, F. Ploquin, M. Soressi, W. Rendu, R. Macchiarelli, A. El Albani, A. Meunier, "Clay minerals of late Pleistocene sites (Jonzac and Les Cottés, SW France): Applications of X-ray diffraction analyses to local paleoclimatic and paleoenvironmental reconstructions", Quaternary International, vol. 302, pp. 184-198, 2013. https://doi.org/10.1016/i.quaint.2012.12.011.

[15]M. Li, S. Sun, X. Fang, C. Wang, Z. Wang, H. Wang, "Clay minerals and isotopes of Pleistocene lacustrine sediments from the western Qaidam Basin, NE Tibetan Plateau", Applied Clay Science,vol. 162, pp. 382-390, 2018. https://doi.org/10.1016/j. clay.2018.06.033.

[16]H. Chamley, Clay sedimentology. Springer, Berlin, Heidelberg, 623 p., 1989.

[17]Latvian lake data base "Ezeri.lv". [Online]. Available: https:// www.ezeri.lv/database/ [Accessed: Apr. 2, 2019]

[18]D. M. Moore and R. C. Reynolds, Jr., X-Ray Diffraction and the Identification and Analysis of Clay Minerals, Oxford University Press, New York, 1989.

[19] ICDD Phase Identification \& Quantitation data base PDF-4/Organics2017 . [Online]. Available: www.icdd.com/index.php/pdf-4 [Accessed: Feb. 3, 2019]

[20]A. Stinkule, Māli Latvijas zemes dzīlēs. [Clay in the bowels of the earth of Latvia] Rīga, RTU izdevniecība, 2014.

[21]R. A. Berner, E. L. Sjoberg, M. A. Velbel, M. D. Krom, "Dissolution of Pyroxenes and Amphiboles During Weathering", Science, vol. 207, no. 4436, pp. 1205-1206, 1980.

[22] J. Xiao, J. Fan, L. Zhou, D. Zhai, R. Wen, X. Qin, "A model for linking grain-size component to lake level status of a modern clastic lake", Journal of Asian Earth Sciences, vol. 69, pp. 149-158, 2013. https://doi.org/10.1016/j.jseaes.2012.07.003.

[23] Jule Xiao, Jiawei Fan, Dayou Zhai, Ruilin Wen, Xiaoguang Qin, "Testing the model for linking grain-size component to lake level status of modern clastic lakes", Quaternary International, vol. 355, pp. 34-43, 2015. https://doi.org/10.1016/j.quaint.2014.04.023.

\section{ACKNOWLEDGMENTS}

European Regional Development Fund Postdoctoral research aid Nr.1.1.1.2/16/I/001 research application "Identification of blue clay in lakes of Latgale region and possibilities of its application, Nr.1.1.1.2/VIAA/1/16/131". We are grateful to anonymous reviewer for constructive criticism and suggestions.
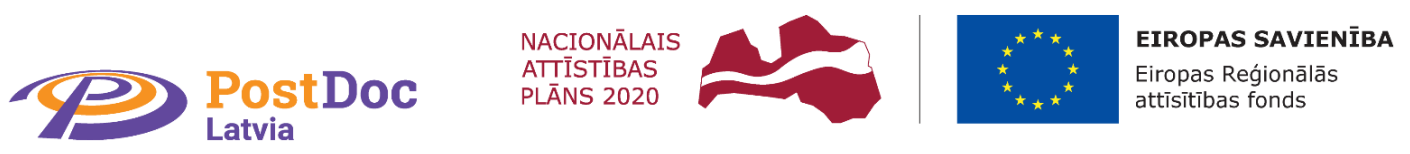

I E G U L D I J U M S TA $V \bar{A} \quad N \bar{A} K O T N \bar{E}$ 